\title{
IN VIRTO AND IN VIVO PHOSPHORYLATION OF A COAT PROTEIN OF POTATO VIRUS X
}

\author{
L.O. Maksymenko, N.Y. Parkhomenko \\ Zabolotny Institute of Microbiology and Virology, NAS of Ukraine, \\ 154 Acad. Zabolotny Str., Kyiv, 03143, Ukraine \\ e-mail:maksymenko.l.a@gmail.com
}

\begin{abstract}
At the present stage of development of plant virology the study of molecular mechanisms of regulation, translation and replication of viral RNA is of great interest. Potato virus X (PVX) RNA in viral particles is not available for in vitro translation, but acquires the ability to be translated as a result of shell protein phosphorylation. The aim of our study was to investigate the conditions of phosphorylation of the PVX coat protein in in vitro and in vivo systems, as well as the effect of EDTA and $\mathrm{CaCl}_{2}$ on the phosphorylation in vitro. Methods. The PVX coat protein was obtained by the guanidine chloride method. The kinase activity of PVX protein in vitro was determined in a standard reaction mixture containing $\mathrm{Mn}^{2+}$ ions, $0.8 \mathrm{mM}$ EDTA, and 2 micro $\mathrm{Ci}^{32} \mathrm{P}$ ATP $(3000 \mathrm{Ci} / \mathrm{mM})$. Phosphorylation of the protein in vivo was carried out by immersing Datura stramonium leaves with symptoms of $P V X$ infection in water containing $\mathrm{K}_{3} \mathrm{PO}_{4}{ }^{32} \mathrm{P}$. After isolation of $\mathrm{PVX}$ from the leaves, the viral coat protein was fractionated by SDS-PAAG electrophoresis. Fractions of the protein were transferred from the gel by contact manner on a nitrocellulose filter. The PVX coat protein was detected by immunoblotting using immunoglobulins to PVX coat protein and rabbit antibodies labeled with peroxidase. The inclusion of labeled phosphorus in the PVX protein was detected by radioautography. Results. The PVX coat protein was phosphorylated in vitro in a standard incubation medium containing (gamma ${ }^{32} P$ ) ATP. In contrast, the PVX coat protein cannot be phosphorylated in the same conditions in the presence of (alpha- ${ }^{32} P$ ) ATP. In vivo phosphorylated PVX coat protein was detected by exposing nitrocellulose filter with immunoblot on X-ray film. Additionally, it was found that the presence of $10 \mathrm{~mm} E D T A$ and $10 \mathrm{~mm} \mathrm{CaCl}$, inhibited the process of the PVX coat protein phosphorylation in vitro. Conclusions. The coat protein of potato virus $X$ is able to phosphorylate in vitro and in vivo systems. The terminal ATP phosphate plays a major role in the phosphorylation of the PVX coat protein. The presence of EDTA and $C a^{2+}$ influences on the process of protein phosphorylation in vitro. These agents are able to inhibit the process of phosphorylation of the PVX coat protein. Thus, the phenomenon of phosphorylation of the PVX coat protein apparently indicates about its participation in the regulation of the virus reproduction in the infected cell.
\end{abstract}

Keywords: potato virus $X, P V X$ protein, phosphorylation, protein kinase.

Phosphorylation of capsid proteins is characteristic for many plant viruses. Phosphorylation of structural proteins in cauliflower mosaic virus, potato virus A (PVA), plum beetle virus, etc. is described [1]. This process is necessary for the development of viral infection in the plant. It was shown that the coat proteins of different viruses can be phosphorylated only in released state [1]. Phosphorylation of the free coat protein of PVA regulates its ability to interact with virus RNA. At the later stages of infection, it is dephosphorylated and the assembly of viral particles is activated $[1,2]$. The phosphorylation of proteins leads to decreasing of the efficiency of protein-RNA binding and inhibition of the ability to homologous protein-protein interactions [3].
Potato virus $\mathrm{X}$ is a typical representative of the genus Potexvirus. The role of the transport form of potexviruses performs by either mature viral particle or by RNA in complex with a coat protein and one of the three other virus transport proteins [4]. As far as virus phosphorylated proteins are involved in the regulation of viral infection inside cells, it was expected that these viral proteins are eligible to phosphorylation-dephosphorylation process during the development of infection [1-4]. The same was shown for the plum shell virus $[2,3]$.

PVX RNA in the composition of viral particles is not available to translation in vitro, but acquires this ability after phosphorylation of the coat protein [4]. In this regard, the aim of our research was to study the conditions of phosphorylation of the coat 
protein of potato virus $\mathrm{X}$ (PVX protein) in vitro and in vivo, as well as the effect of EDTA and $\mathrm{CaCl}_{2}$ on phosphorylation of this viral protein in vitro.

\section{Materials and methods}

Potato virus X was obtained from Datura stramonium leaves with typical symptoms of infection. To the leaves homogenate was added up

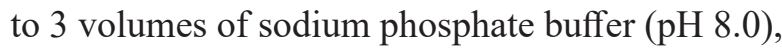
which contained $0.2 \%$ mercaptoethanol. The filtrate was centrifuged at $3000 \mathrm{~g}$ for 10 minutes. The supernatant was centrifuged for $10 \mathrm{~min}$ at $10000 \mathrm{~g}$. Next, Triton X-100 was added to the supernatant to final concentration $0.5 \%$ and the mixture was incubated for $30 \mathrm{~min}$. The virus was precipitated with PEG 6000, bringing it to a final concentration of $4.5 \%$ and $\mathrm{NaCl}$ to $2 \%$. The virus precipitate was obtained after centrifugation at $10000 \mathrm{~g}$ for 15 minutes and dissolved in phosphate buffer $(\mathrm{pH}$ 7.0). The virus concentration was determined on a Specord spectrophotometer at a wavelength of $260 \mathrm{~nm}$ in UV light [5].

Structural viral protein was obtained by the method [6]. To $1 \%$ suspension of potato virus $\mathrm{X}$ an equal volume containing $5.3 \mathrm{M}$ guanidine, 3.3 M LiCl, 0.01 M 2-mercaptoethanol, $0.02 \mathrm{M}$ boric acid, $0.01 \mathrm{M} \mathrm{NaOH}$ was added. The mixture was incubated at $4{ }^{\circ} \mathrm{C}$ with periodic stirring for 2 days. Under such conditions, the protein goes into solution, and RNA forms precipitate. The protein solution was centrifuged. The purified protein was then dialyzed against one hundred times the volume of distilled water for two days, the water was periodically changed. Protein concentration was measured on a spectrophotometer, using the absorption coefficient [6].

Rabbit antiserum to PVX protein was obtained by immunizing the rabbit intravenously every 7 days for a month. Then, after 10 days, blood was collected and serum was separated. Serum titer was determined by double diffusion in $1 \%$ agar as described by Ouchterlony [7]. Serum with a titer of 1:32 was used in the work.

Phosphorylation of PVX protein in vivo was determined as follows. Chopped leaves of Datura stramonium infected with PVX with specific symptoms were immersed in distilled water containing $375 \mathrm{mCi}$ of ${ }^{32} \mathrm{P}$, and incubated for 5 days until the leaves completely absorbed the labeled water. Potato virus X was isolated from the leaves. The PVX coat protein was fractionated by SDSPAGE. The protein from the gel was transferred to nitrocellulose filter by contact manner. Immunoblot of PVX coat protein was carried out by Towbin [8].
Specific serum to PVX coat protein and peroxidaselabeled anti-rabbit antibodies were used for this purpose.

The kinase activity of the studied proteins in vitro was determined as described in [9]. The following reaction mixture comprised of: $20 \mathrm{mM}$ Tris $\mathrm{HCl} \mathrm{pH} \mathrm{7.4,} 10 \mathrm{mM} \mathrm{MnCl}_{2}, 0.8 \mathrm{mM}$ EDTA and 2 micro $\mathrm{Ci}^{32} \mathrm{P}$ ATP $(3000 \mathrm{Ci} / \mathrm{mM})$. The standard mixture was prepared 2 times more concentrated; an equal volume of test proteins was added and incubated for $60 \mathrm{~min}$ at $37^{\circ} \mathrm{C}$. In order to fractionate the proteins in SDS PAGE, trichloroacetic acid was added to the samples to a final concentration of $10 \%$. The insoluble fraction was washed three times with alcohol, dissociating buffer was added, heated at $100{ }^{\circ} \mathrm{C}$ for 5 minutes and analyzed in $8-20 \%$ gradient PAGE. The electrophoresis was performed according to Laemmli [10]. Phosphorylated in vitro and in vivo proteins were detected by radioautography on RM-1 film. For this purpose, the dried gel or nitrocellulose filter was exposed to the film for 12 hours.

\section{Results}

The previously obtained solution of PVX protein was measured using spectrophotometer. Fig. 1 shows the absorption spectrum of the protein in UV light at $280 \mathrm{~nm}$.

The molecular weight of PVX protein was determined by $10 \%$ SDS-PAGE and corresponded to $29 \mathrm{kD}$ (Fig. 2).

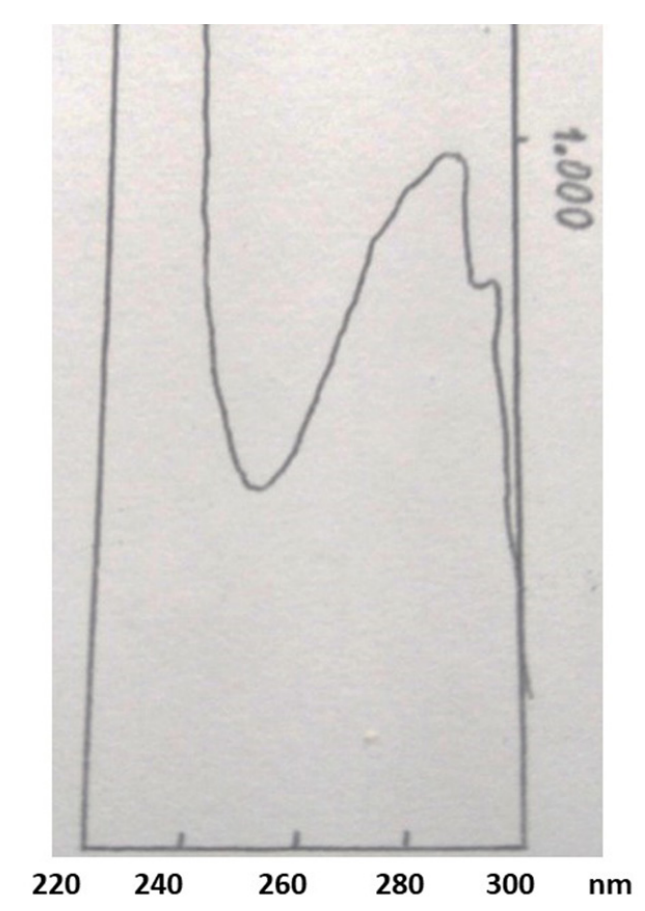

F i g. 1. UV spectrum of PVX protein 


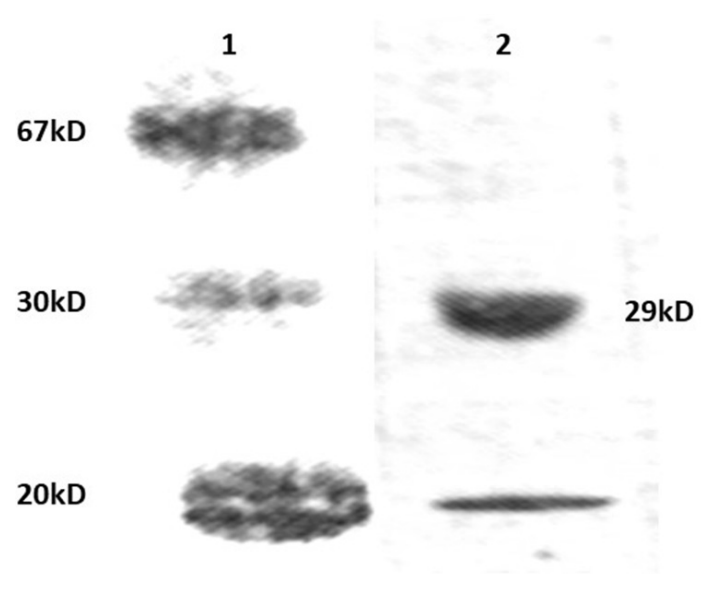

F i g. 2. Electrophoregram of the PVX protein: 1 - markers, 2 - PVX protein of $29 \mathrm{kD}$ weight

To a standard reaction medium containing $1-$ (gamma ${ }^{32} \mathrm{P}$ ) ATP and $2-\left(\right.$ alpha ${ }^{32} \mathrm{P}$ ) ATP an aliquot of $20 \mu \mathrm{L}$ of PVX protein solution was added. The phosphorylation products were thoroughly washed off from the label, fractionated in SDS-PAGE, the gel was dried and exposed to X-ray film. As can be seen from the autoradiography (Fig. 3), PVX protein was phosphorylated in in vitro system contained (gamma ${ }^{32} \mathrm{P}$ ) ATP and not phosphorylated in a system with (alpha ${ }^{32} \mathrm{P}$ ) ATP. Having such properties, the structural viral protein, apparently, may be involved in the regulation of protein synthesis in the infected cell. Fig. 4 shows the autoradiography of phosphorylation of PVX protein in in vivo system. Autoradiographs were obtained after exposure to X-ray film of the nitrocellulose filter after immunoblotting using anti-PVX protein serum. Thus, PVX protein can be phosphorylated in PVX-infected Datura stramonium leaves. It should be noted that along with the phosphorylation of the viral protein, products of its proteolytic cleavage can also be phosphorylated. This proteolysis, apparently, is a result of activity of cell proteases.

Viral proteins transferring from cell to cell can be phosphorylated-dephosphorylated by cellular kinases and phosphatases, and viruses use these processes for the development of infection. The genomes of most plant viruses do not encode their own protein kinases thus they utilize plant cell enzymes such as calcium- and cyclin-dependent protein kinases. The last ones are involved in the regulation of the cell cycle. In addition, their activity is regulated by phosphorylationdephosphorylation. In this regard, our next task was to investigate the effect of chelating agent EDTA, as well as $\mathrm{Ca}^{2+}$ on the process of phosphorylation of the PVX protein. These reagents were separately added to the standard incubation medium to the final concentration $10 \mathrm{mM}$ both. The $20 \mu \mathrm{L}$ of PVX protein in concentration $1 \mathrm{mg} / \mathrm{mL}$ was added to the reactions and incubated as mentioned above. The results of the reaction were visualized in 10\% SDSPAGE with subsequent detection on X-ray film. The obtained autoradiography of the viral protein indicates that the presence of $10 \mathrm{mM}$ EDTA and $10 \mathrm{mM} \mathrm{CaCl}{ }_{2}$ inhibited the process of phosphorylation of the PVX protein in the in vitro system (Fig. 5).
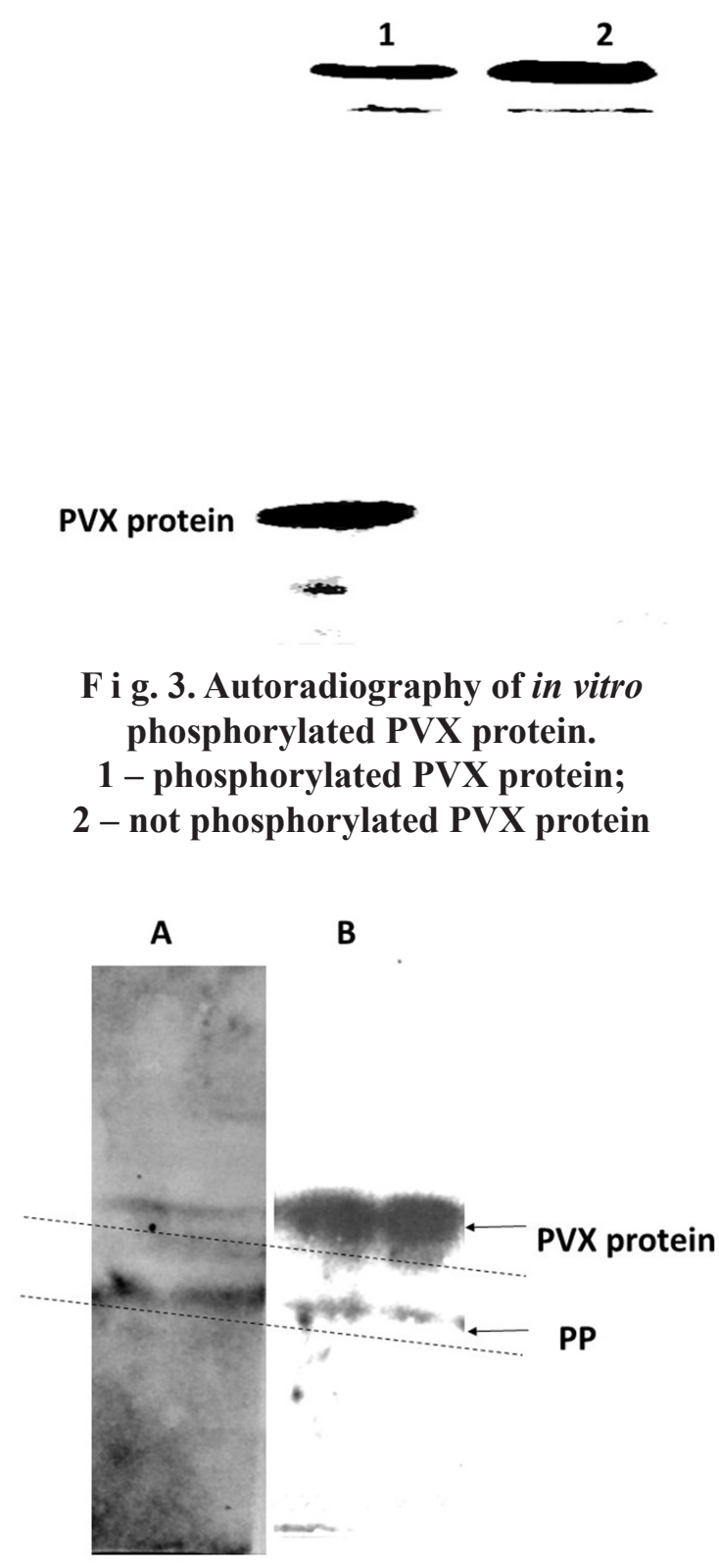

F i g. 4. Phosphorylation in vivo of the PVX protein: A - an immunoblot with anti-PVX protein-serum; B - an autoradiography of the ${ }^{32} \mathrm{P}$-labelled $\mathrm{PVX}$ protein from ${ }^{32} \mathrm{P}$-treated leaves of Datura stramonium with specific symptoms of PVX infection; $\mathbf{P P}$ - proteolysis products 


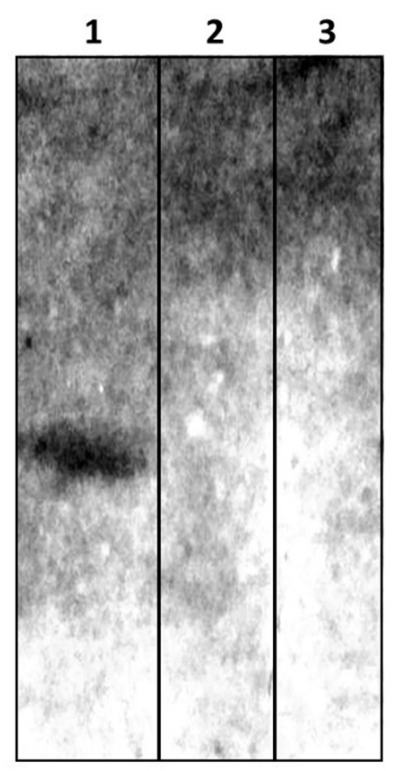

\section{$\mathrm{F}$ i g. 5. The effect of EDTA and $\mathrm{CaCI}_{2}$ on phosphorylation of $\mathrm{PVX}$ protein in vitro - radioautography ${ }^{32} \mathrm{P}$-labelled proteins: 1 - phosphorylated ${ }^{32} \mathrm{P}$-labelled $\mathrm{PVX}$ protein from the standard incubation medium $(\mathrm{C})$; \\ $2-(\mathrm{C})+10 \mathrm{mM}$ EDTA+PVX protein (phosphorylation inhibited); \\ $3-(\mathrm{C})+10 \mathrm{~mm} \mathrm{CaCl}+\mathrm{PVX}$ protein (phosphorylation inhibited)}

\section{Discussion}

Phosphorylation is the process of transferring a terminal phosphate group from ATP to the corresponding serine or threonine residue. This process is carried out by protein kinases. These enzymes differ in substrate specificity and in the mechanisms of regulation of their activity. There are a number of activators of protein kinases cyclic adenosine monophosphate (cAMP), ions of calcium, magnesium, manganese, double-stranded RNA, and others [3].

Currently, the study of molecular mechanisms of regulation of translation and replication of viral RNA are still extremely significant. Oparka and coauthors [11] proposed a model according to which, the viral RNA becomes available for translation in infected cell after phosphorylation of the virus coat protein by host plant kinases. In the subsequent cycle of virus reproduction, RNA is "dressed" by the coat protein. Thus, it become temporarily excluded from translation and replication, and moving though plasmodesma to neighbor cells. It is possible that phosphorylation is responsible for the destruction of the replicative complex.

It is possible to assume that in the middle and late stages of virus infection there is an inhibition of protein kinase activity in PVX infected cells, which contributes to the formation of mature virions. It is known that protein kinases of total tobacco leaf extract are able to phosphorylate the coat protein of the potato virus A, as well as the transport protein of tobacco mosaic virus (TMV). Both kinase reactions were independent of $\mathrm{Ca}^{2+}$ and were activated by $\mathrm{Mn}^{2+}$ more efficiently than $\mathrm{Mg}^{2+}[1,4]$. A possible mechanism of stimulation of protein kinases by divalent metal cations is the formation of a complex of these cations with ATP, and subsequent use of this complex by the enzyme [1].

The authors [12] showed that the binding of TMV RNA with a transport protein leads to inhibition of its translation in vitro. It has been suggested that in vivo activation of the transport protein-RNA complex occurs during its passage through the plasmodesma and is carried out by phosphorylation of the transport protein.

Earlier, we detected in mRNP (informosomes) the in vitro phosphorylated proteins induced by the PVX in Datura stramonium plants. A protein with cAMP-dependent protein kinase activity was detected in these virus-specific informosomes. This protein was identified as an RNA-dependent RNA polymerase and able to direct the synthesis of a double-stranded RNA in the replication system in vitro [13]. There is information about the role of phosphorylated capsid protein of potato virus A in the initiation of viral RNA translation, as well as its relationship with RNA-dependent RNA polymerase [14]. Phosphorylation of protein components of RNA replication complex has been shown for three groups of viruses $[2,13,14]$.

There are also data on the in vivo phosphorylation of the TMV capsid protein [15].

Regulation of viral RNA replication and translation by phosphorylation of capsid proteins is characteristic of Hepacivirus $\mathrm{C}$ virus $[16,17]$. Thus, the effect of capsid protein phosphorylation on viral genome expression is essential for both plant and animal viruses. The research on the processes of phosphorylation-dephosphorylation of capsid proteins in cells during viral infection and their impact on the reproduction of viruses is a highly relevant topic in virology.

Thus, the capsid proteins of potato virus $X$ can be multifunctional after the processes of phosphorylation-dephosphorylation. We have shown that PVX protein is able to phosphorylate in in vitro and in vivo systems. The phenomenon of phosphorylation of the PVX coat protein occurs 
due to association with plant protein kinases during reproduction of the virus.

\section{ФОСФОРИЛЮВАННЯ КАПСИДНОГО БІЛКА Х-ВІРУСУ КАРТОПЛІ В СИСТЕМАХ IN VITRO I IN VIVO}

\section{Л.О. Максименко, Н.Й. Пархоменко}

Інститут мікробіології і вірусологї ім. Д.К. Заболотного НАН України, вул. Академіка Заболотного, 154, Київ, 03143, Україна

\section{Резюме}

На сучасному етапі розвитку вірусології рослин великий інтерес представляє вивчення молекулярних механізмів регуляції процесів трансляції і реплікації вірусних РНК. РНК X-вірусу картоплі (ХВК) у складі вірусних часток недоступна для трансляції in vitro, але набуває здатності транслюватись в результаті фосфорилювання білка оболонки. Метою нашого дослідження було вивчення умов фосфорилювання білка ХВК в системах in vitro i in vivo, а також впливу ЕДТА та $\mathrm{CaCl}_{2}$ на фосфорилювання вірусного білка в системі in vitro. Методи. Капсидний білок ХВК одержували гуанідин-хлоридним методом. В стандартній реакційній суміші, яка містила іони $\mathrm{Mn}^{2+}$ та 0,8 mM EDTA і 2 мікро Сі- гама ${ }^{32} \mathrm{P}$ АТФ(3000 Ci/ $\mathrm{mM})$, визначали здатність капсидного білка ХВК фосфорилюватись in vitro. Фосфорилювання вірусного білка ХВК in vivo проводили шляхом занурювання листя дурману з симптомами ураження ХВК у воду, яка містила $\mathrm{K}_{3} \mathrm{PO}_{4}{ }^{32} \mathrm{P}$. ХВК виділяли 3 листя Datura stramonium, отриманий білок фракціонували методом електрофорезу в ПААГ. Фракції білка з гелю контактним чином переносили на

1. Ivanov KI, Puustinen P, Merits A, Saarma M, Makinen K. Phosphorylation down-regulates the RNA binding function of the coat protein of potato virus A. J Biol Chem. 2001; 276(17):1353040.

2. Law LMJ, Everitt JC, Beatch MD, Holmes CF, Hobman TC. Phosphorylation of rubella virus capsid regulates its RNA binding activity and virus replication. J Virol. 2003; 77(3):176471.

3. Makarov VV, Iconnicova AY, Kalinina NO, Guseunov MA, Vishnichenko VK. In vitro phos- нітроцелюлозний фільтр, вірусний білок виявляли методом імуноблоту з застосуванням імуноглобулінів до білка ХВК і антикролячих антитіл, мічених пероксидазою. Включення міченого фосфору в білок ХВК виявляли методом радіоавтографії на плівці РМ-1. Результати. Встановлено, що капсидний білок X-вірусу картоплі здатний фосфорилюватись у стандартному інкубаційному середовищі in vitro, яке містило( гама $\left.-{ }^{32} \mathrm{P}\right)$ АТФ. На відміну від цього білок ХВК у стандартному інкубаційному середовищі при наявності (альфа- $\left.{ }^{32} \mathrm{P}\right)$ АТФ не фосфорилюється. Таким чином, кінцевий фосфат АТФ відіграє головну роль у фосфорилюванні білка ХВК. Маючи такі властивості, структурний вірусний білок, мабуть, бере участь у регуляції синтезу вірусспецифічних білків в інфікованій клітині. Фосфорильований капсидний білок ХВК в системі in vivo був виявлений шляхом експонування нітроцелюлозного фільтру 3 імуноблотом вірусного білка на рентгенівській плівці РМ-1. Таким чином, був одержаний радіоавтограф фосфорильованого in vivo білка ХВК. Наявність в інкубаційній системі in vitro $10 \mathrm{мM}$ ЕДТА та 10 мМ CaCl 2 пригнічувало процес фосфорилювання білка ХВК. Явище фосфорилювання капсидного білка ХВК, мабуть, використовується в процесах репродукції вірусу в інфікованій клітині. Висновки. Капсидний білок Х-вірусу картоплі здатний фосфорилюватись в системах in vitro i in vivo. Білок ХВК фосфорилюється завдяки кінцевого фосфату АТФ. На процес фосфорилювання білка in vitro впливає наявність ЕДТА та іонів $\mathrm{Ca}^{2+}$. Ці агенти здатні пригнічувати процес фосфорилювання вірусного білка ХВК.

Ключові слова: X-вірус картоплі, капсидний білок ХВК, фосфорилювання, протеїнкінази.

phorilation of the N-terminal half of hordeivirus movement protein. Biochemistry (Moscow). 2012; 77(9):1072-81.

4. Atabekov JG, Rodionova NP, Karpova OV, Kozlovsky SV, Novikov VK, Arkhipenko MV. Translation activation of encapsidated potato virus X RNA by coat protein phosphorylation. Virology. 2001; 286(2):466-74.

5. Koenig H, Tremaine JH, Shepard JF. In situ degradation of the protein chain of potato virus $\mathrm{X}$ at the N- and C-termini. J Gen Virol. 1978; 38(2):329-337. 
6. Wu G, Bruening G. Two proteins from cowpea mosaic virus. Virology.1971; 46(3):596-612.

7. Ouchterlony O. Handbook of immunodiffusion and immunoelectrophoresis. Ann Arbor Science Publishers; 1968.

8. Towbin H, Stalhelin T, Gordon J. Electrophoretic transfer of proteins from polyacrylamide gels to nitrocellulose sheets: procedure and applications. Proc Nat Acad Sci USA. 1979; 76(9):4350-4.

9. Menissier-de Murcia J, Geldreich A, Lebeurier J. Evidence for a protein kinase activity associated with purified particles of cauliflower mosaic virus. J Gen Virol. 1986; 67:1885-91.

10. Laeimmli UK. Cleavage of structural proteins during the assembly of the head of bacteriophage T4. Nature. 1970; 227(5259):680-5.

11. Oparka KJ, Roberts AG, Roberts IM, Prior DAM, Santa Crus S. Viral coat protein is targeted to, but does not gate, plasmodesmata during cell to cell movement of potato virus X. Plant J. 1996;10(5):805-13.

12. Karpova OV, Rodionova NP, Ivanov KI, Kozlovsky SV, Dorokhov YuL, Atabekov IG. Phosphorylation of tobacco mosaic virus movement protein abolishes its translation repressing ability. Virology. 1999; 261(1):20-4.

13. Didenko LF, Maksymenko LA, Parkhomenko NI. [In vitro phosphorylation of informosome proteins from leaves of Datura stramonium infected with potato X-virus]. Mikrobiol Z. 1993; 55(2):68-74. Russian.

14. Fellers J, Wan J, Hong Y, Collins GB, Hunt AG. In vitro interactions between a potyvirus-encoded, genome linked protein and RNA-dependent RNA-polymerase. J Gen Virol. 1998; 79(8):2043-9.

15. Watanabe Y, Ogawa T, Okada Y. In vivo phosphorylation of the $30 \mathrm{kDa}$ protein of tobacco mosaic virus. FEBS Letters. 1992; 313(2):181-4.

16. Cao L, Yu B, Kong D, Cong Q, Yu T, Chen Z. Functional expression and characterization of the envelope glycoprotein E1E2 heterodimer of hepatitis C virus. PLoS Pathog. 2019; 15(5):e1007759

17. Sokolova TM. [Hepatitis C virus (Flaviviridae: Hepacivirus:Hepacivirus $\mathrm{C}$ ): regulation of signaling reactions of innate immunity]. Problems of Virology. 2020; 65(6):307-16. Russian.

Received 2.06.2021 